\title{
Determination The Status of Utilization and Level of Sepat (Trichogaster sp) in freshwaters of Banjar Regency
}

\author{
Novita Sari, Iriansyah, Irhamsyah* \\ Department of Fisheries Resources Utilization, Faculty of Fisheries and Marine Sciences, Lambung Mangkurat \\ University, Banjarbaru, Indonesia, 70714. \\ * Correspondence: irhamsyah.asmuni@rocketmail.com
}

Received: 25 September 2019; Accepted: 17 November 2019; Published: 21 November 2019

\begin{abstract}
The fishing of Sepat (Trichogaster $s p$ ) in freshwaters of Banjar Regency with a solid intensity that has lasted long enough. This study aims: (1) Knowing the model of surplus production that can be used (2) Knowing the optimum effort Sepat (3) Knowing the maximum sustainable yield (4) Knowing the utilization level of Sepat (5) Knowing the effort level of Sepat. The method that used in this research was survey method and collecting data. Data was analyzed by the Schaefer's model and Fox's model. The result of this research: (1) The best model is the Schaefer model with R2 and validation value (2) The catch rate of Sepat was 45630 trip per year (3) Maximum sustainable yield of Sepat was 45,466 ton per year. (4) The utilization rate of Sepat (Trichogaster sp) was 33\% which shows there no more catch under fishing (5) Effort level of Sepat was $16 \%$.
\end{abstract}

Keywords: fox model, maximum sustainable yield, schaefer model, sepat (trichogaster sp), surplus production model.

\section{Introduction}

Fishing in the freshwaters in South Kalimantan are generally carried out in rivers, swamps, lakes and reservoirs. Fish that are usually caught are local fish. In 2012 the production of Sepat fish resources. Data on the level of fish utilization in water is very important because it determines the utilization of these resources is less than optimal, optimal, or even overfishing. Excessive use of fish will threaten the sustainability of the fish. Knowing the level of utilization of Sepat resources is expected to be carried out in a planned management.

The Surplus Production Model is one of the simplest fish stock valuation models and is easily explained and accepted by fish resource managers. The basic assumption of this model is the entity's fish resources, without taking into account the actual processes that are not simple that causes the formation of the entity. Experts claim this model simplifies the process. This model only requires data capture and effort, these two types of data are usually known as fisheries characteristics. So, it is necessary to know the characteristics of fish resources, behavior and limits of the resilience of fish resources to fishing pressure (Badrudin, 2004).

Formulation of the Problem:

1. What is the best surplus production model that can be used for catching Sepat (Trichogaster sp)?

2. What is the level of catching Sepat (Trichogaster sp)?

3. What is the maximum result catching of Sepat (Trichogaster $s p$ )?

4. What is the utilization rate of Sepat (Trichogaster $s p$ )?

5. What is the level effort of Sepat (Trichogaster $s p$ )?

Research purposes: 
1. Find out the best surplus production model that can be used for catching Sepat (Trichogaster $s p$ )

2. Find out the level of catching Sepat (Trichogaster $s p$ )

3. Find the maximum result catching of Sepat (Trichogaster $\mathrm{sp}$ )

4. Find out the utilization rate of Sepat(Trichogaster $s p$ )

5. Find out the level effort of Sepat (Trichogaster sp)

\section{Materials and Methods}

Time and Place

This research was carried out for 4 months from the preparation until the report, from June to September 2017. It is located in Banjar Regency, South Kalimantan Province.

Research Methods

This research was conducted using survey methods. The data collected is primary data and secondary data. This research uses data with field observations.

Primary data collection is done through direct observation of fishing units as well as interviews with fishermen using questions that fit the research objectives. Data obtained from the Banjar Regency Fisheries Statistics data, the Banjar Regency Maritime Affairs and Fisheries Agency, the relevant agencies and through searching various libraries.

Analysis Data

1. Schaefer's Model

The Surplus Production Model developed by Schaefer, whose initial form same as the logistical growth model.

2. Fox's Model

The Fox model (1970) in Kekenusa, Rondonuwu, Paendong, and Weku, 2014 has several different characteristics from the Schaefer model, namely biomass growth following the Gompertz growth model. The decrease in CPUE to capture attempts follows a negative exponential pattern.

\section{Results and Discussion}

Result

The catch rate of Sepat (Trichogaster sp)

Table 1. Number of production of sepat (Trichogaster $s p$ ) in Banjar District by Type of Fishing Gear in 2012-2016.

\begin{tabular}{lrrrrr}
\hline & \multicolumn{7}{c}{ Production / year (ton) } \\
\cline { 2 - 6 } Type of fishing gear & $\mathbf{2 0 1 2}$ & $\mathbf{2 0 1 3}$ & $\mathbf{2 0 1 4}$ & $\mathbf{2 0 1 5}$ & $\mathbf{2 0 1 6}$ \\
\hline Anco & 1,5 & 0,2 & 5,1 & 1,4 & 3,6 \\
Jaring Insang & 1,2 & 0,8 & 9,1 & 3,5 & 6,2 \\
Lukah & 3,9 & 0,4 & 2,1 & 1,5 & 1,4 \\
Pancing & 3,0 & 2,3 & 8,0 & 3,4 & 0,4 \\
Tempirai & 0,4 & 0,6 & 9,7 & 6,9 & 3,4 \\
\hline Total & $\mathbf{1 0 , 0}$ & $\mathbf{4 , 3}$ & $\mathbf{3 4 , 0}$ & $\mathbf{1 6 , 7}$ & $\mathbf{1 5 , 0}$ \\
\hline
\end{tabular}

Source : Data from the Banjar Regency Fisheries and Maritime Agency

Fishing efforts (Trichogaster $s p$ ) 
The number of trips of each fishing gear in Banjar Regency within a period of 5 years (2012-2016)

Table. 2

\begin{tabular}{llllll}
\hline \multirow{2}{*}{$\begin{array}{c}\text { Type of fishing } \\
\text { gear }\end{array}$} & \multicolumn{5}{c}{ Trip / year } \\
\cline { 2 - 6 } & $\mathbf{2 0 1 2}$ & $\mathbf{2 0 1 3}$ & $\mathbf{2 0 1 4}$ & $\mathbf{2 0 1 5}$ & $\mathbf{2 0 1 6}$ \\
\hline Anco & 1236 & 476 & 3519 & 5618 & 2835 \\
Jaring Insang & 789 & 1303 & 5721 & 3729 & 3330 \\
Lukah & 1778 & 1825 & 6871 & 7200 & 5649 \\
Pancing & 2124 & 2247 & 7729 & 2408 & 395 \\
Tempirai & 1144 & 360 & 6065 & 5256 & 6240 \\
\hline
\end{tabular}

Source : Data from the Banjar Regency Fisheries and Maritime Agency

Schaefer's Model

From the analysis results obtained by the regression equation as follows $\frac{C_{t}}{E_{t}}=0,001992838-$ $2,18368 \mathrm{E}-08 \mathrm{E}_{\mathrm{t}}$ with the coefficient of determination $\mathrm{R}^{2}=0,246613491$ and level of significance $(\mathrm{p}<$ $0,05)$.

Fox's Model

From the analysis results obtained by the regression equation as follows: $\operatorname{Ln} \frac{C_{t}}{E_{t}}=-6,22628274-$ 1,21186E-05 with $\mathrm{R}^{2}=0,243724618$ and level of significance $(\mathrm{p}<0,05)$. Combined Results and Discussion section is recommended. Results should be clear and concise. Discussion should explore the significance of the results of the work, not repeat the results. Avoid extensive citations and discussion of published literature.

Discussion

1. Surplus Production Model

These two model used in this research after calculation, the Schaefer model is considered the best model with the support of R2 and validation values, while the Fox's model has a lower R2 value and a large validation value. If the value of R2 approaches the number one, it shows that the model is good and for the validation value, the smaller the value, the more it states that the model is good.

Table. 3 Calculation of data validation for both surplus production models.

\begin{tabular}{lll}
\cline { 2 - 3 } & Schaefer Model & Fox Model \\
\hline $\mathrm{R}^{2}$ value & $\mathbf{0 . 2 4 6 6 1 3 4 9 1}$ & 0.243724618 \\
\hline Validation value & $\mathbf{5 4 , 4 7}$ & 7448,30 \\
\hline $\begin{array}{l}\text { Significance of Individual } \\
\text { Regression Coefficients }\end{array}$ & Not Significant & Not Significant
\end{tabular}

Source: Primary data processed

From the calculation results of Table 3 it appears that the most appropriate is the Schaefer model with a large of $R^{2}$ value $\left(R^{2}=\mathbf{0 . 2 4 6 6 1 3 4 9 1}\right)$ and a small validation value (Validation $\left.=\mathbf{5 4 , 4 7}\right)$, while the significance of the individual regression coefficient of the Schaefer model is not significant. 
2. Level of Catching Efforts

From the Schaefer model obtained $a=0.001992838$ and $b=2.18368 E-08$, with equations (1) and (2) the optimum effort value can be calculated ( $\left.E_{\text {opt }}\right) 45.630$ trip/year. It means that to maintain the sustainability of sepat fishery resources (Trichogaster $s p$ ) in Banjar District in a year the number of fishing units must not exceed 45,630 trips/year.

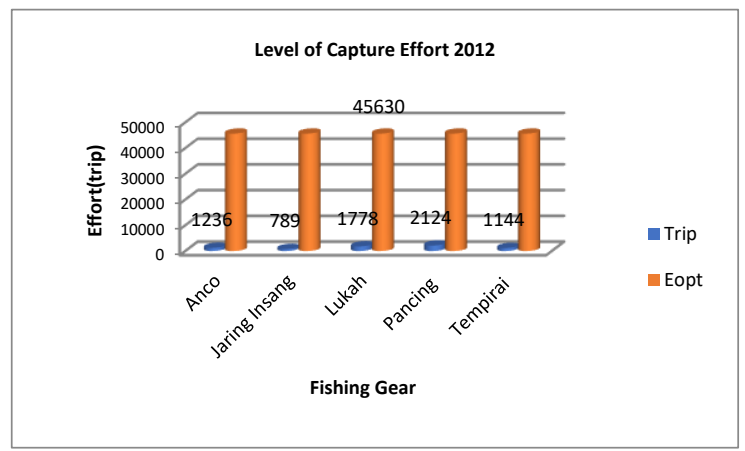

Figure 1. The catch rate of Sepat in 2012.

Based on the chart above, the 2012 fishing effort level of Anco has 1236 trips, 789 trip gills, Lukah 1778 trips, Fishing lines 2124 trips and Tempirai 1144 trips can be stated not to exceed the optimum value.

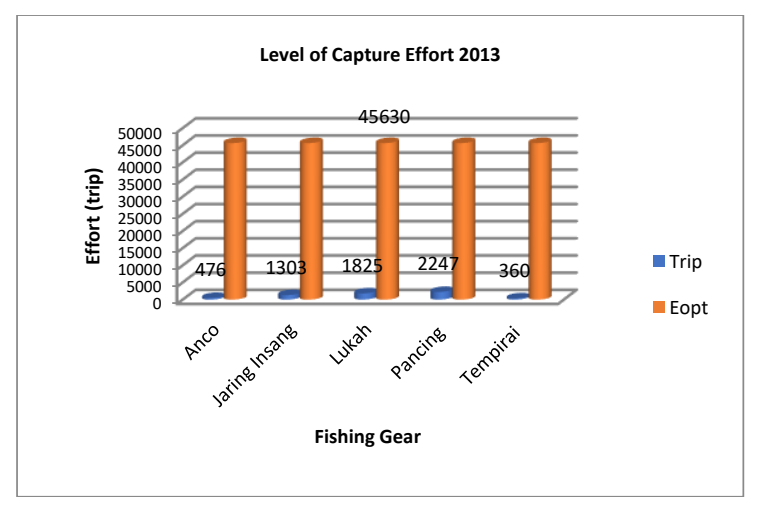

Figure 2. The catch rate of Sepat in 2013.

Based on the graph above that in 2013 the level of capture effort did not exceed the optimum value limit. Anco 476 trip, Gill net 1303 trip, Lukah 1825 trip Fishing line 2247 trip and Tempirai 360 trip.

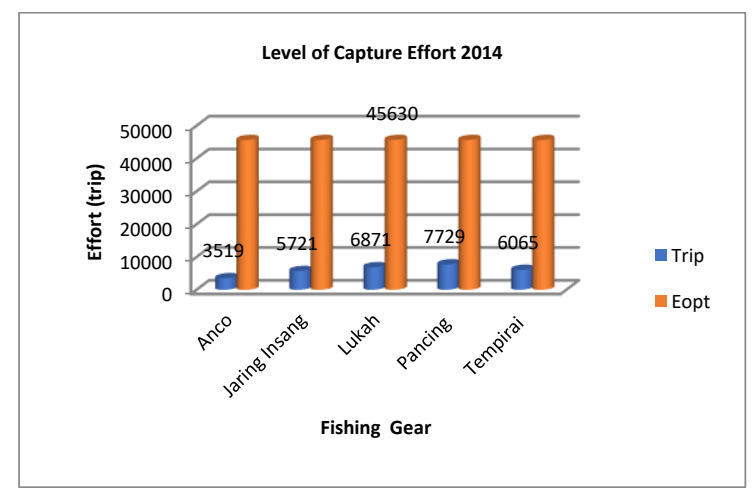

Figure 3. The catch rate of Sepat in 2014.

In 2014 the level of catching effort did not exceed the optimum value limit. Anco 3519 trip, Gill net 5721 trip, Lukah 6871 trip, Fishing line 7729 trip and Tempirai 6065 trip. 


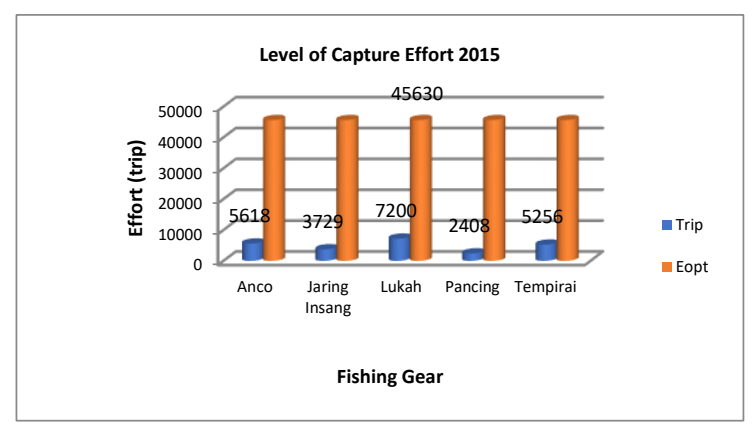

Figure 4. The catch rate of Sepat in 2015.

In 2015 the same as in 2014 the level of capture effort does not exceed the optimum value.

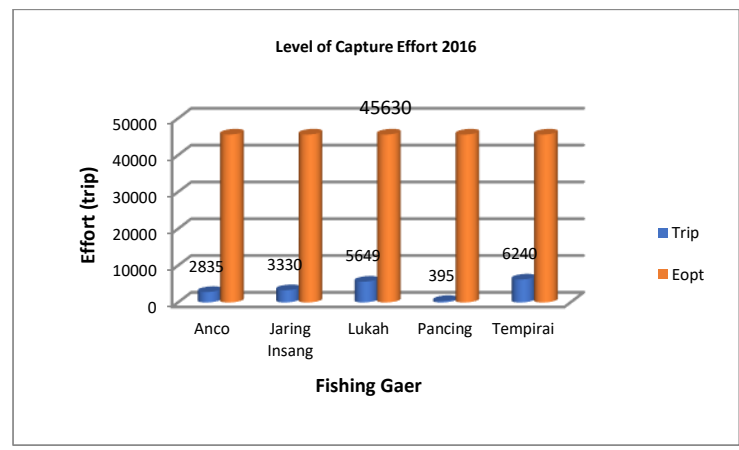

Figure 5. The catch rate of Sepat in 2016.

Based on the level of capture effort from 2012-2016 does not exceed the optimum value so that the number of trips or the fleet can be increased.

The distance of the fishing area is $1.5 \mathrm{~km}$ on the gill net by using a boat or diesel generator-powered genset. The arrest time was from 6:00 a.m. - 4:00 p.m. with a total of two fishermen. For Anco, the location of the fishing area with $100 \mathrm{~m}$ length of fishing time from 17.00-07.00 WITA, does not use a boat or jukung. In the fishing area, the location of the fishing area is $100 \mathrm{~m}$ without using a boat, the fishing time for the morning is 10.00-12.00 pm and for the afternoon at 14.00-18.00 pm. Tempirai and Lukah fishing areas are also almost the same as a $100 \mathrm{~m}$ fishing line, do not use a boat or jukung, when the catch is from 07.00-10.00 WITA and 12.00-15.00 WITA.

3. Maximum Sustainable Yield (MSY)

Maximum Sustainable Yield (MSY) is the maximum value of fishing in waters in maximum sustainable capacity or often called maximum sustainable catch. Through linear regression using Microsoft Excel contained in the attachment to get the value of intercept and slope (Nobunowe, 2007).

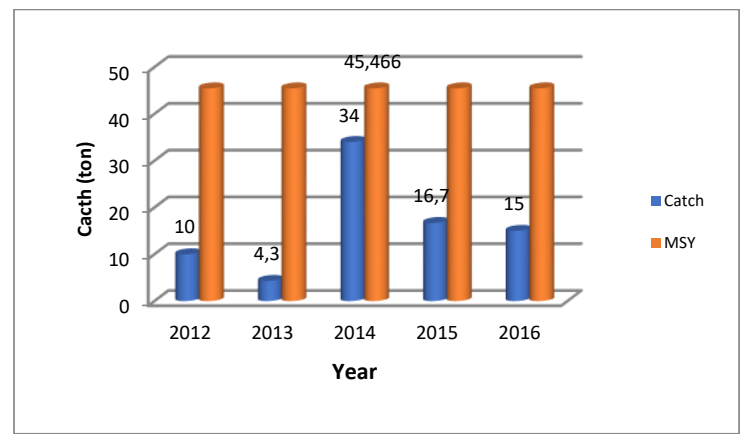

Figure 6. The catch of Sepat (Trichogaster sp) with MSY value.

The basic concept in the smallest scale fisheries management if the policy objective is maximum production, then the optimum exploitation rate is set to achieve Maximum Sustainable Yield, that is the maximum catch that can be obtained on sustainable basis. If the actual catch is less or smaller than MSY due to inadequate fishing efforts, then biologically fisheries as underfishing.

From the results of interviews with fishermen in Sungai Batang Village, Banjar Regency, the gill nets, the biggest catch is per $20 \mathrm{~kg}$, the smallest is $10 \mathrm{~kg}$. Anco catches per trip is the biggest of $3 \mathrm{~kg}$ and the 
smallest is $0.5 \mathrm{~kg}$. The biggest fishing rod per trip is $1-2 \mathrm{~kg}$ and the smallest is $0.5 \mathrm{~kg}$. Capture the catch per trip the largest is $5-6 \mathrm{~kg}$ and the smallest is $2 \mathrm{~kg}$. For Lukah the biggest catch per trip is $5 \mathrm{~kg}$ and the smallest is $1-2 \mathrm{~kg}$.

4. Level of Fish Utilization

Table 4. Sepat Utilization Rate (Trichogaster sp)

\begin{tabular}{ccc} 
Year & Catch (ton) & Utilization Rate (\%) \\
\hline 2012 & 10 & 22 \\
2013 & 4.3 & 9 \\
2014 & 34 & 75 \\
2015 & 16.7 & 37 \\
2016 & 15 & 33
\end{tabular}

Source: Primary data processed

The level of fish utilization is usually seen from the last year's production of 2016 which was 33\%.

Based on the level of utilization of fishery resources used by the national commission on estimating Marine Fish Stock (1997) consists of four levels:

1) Low level if the catch is still a fraction of the potential for sustainable yield (0-33.3\%), where the capture effort still needs to be increased.

2) The level is moderate if the catch has become a real part of the sustainable potential (33.3$66.6 \%$ ) but additional efforts are still possible to optimize yields.

3) The optimum level if the catch has reached a part of the sustainable potential (66.6-99.9\%), the addition of efforts can't increase yields.

4) Overfishing if the catch exceeds the sustainable potential ( $>100 \%)$ and the addition of efforts can be dangerous to the extinction of resources.

5. Fish Utilization Rate

The level of effort can be seen from the last year. If the fish cultivation level> $100 \%$ can be said to be unfit to catch, on the contrary, if the fish cultivation level $<100 \%$ can still carry out fishing operations. The level of Trichogastersp in 2016 is 16\%. This shows that the level of effort does not exceed the optimum limit so that operations can still be carried out.

\section{Conclusions}

1. The best Surplus Production Model used to study the catch of sepat fish (Trichogaster $s p$ ) in fresh waters of Banjar Regency is the Schaefer Model with the support of R2 and validation values.

2. The level of effort to catch sepat (Trichogaster $s p$ ) is 45,630 trips / year

3. The maximum sustainable yield of sepat (Trichogaster $s p$ ) is 45.466 tons / year.

4. The utilization rate of sepat (Trichogaster sp) in 2016 is $33 \%$ including the low level so that production results can still be increased

5. Year 2016 The fish catching rate (Trichogaster $\mathrm{sp}$ ) is $16 \%$ so it can still carry out fishing operations. The main conclusions of the study may be presented in a short Conclusions section, which may stand alone or form a subsection of a Discussion or Results and Discussion section.

\section{References}

Bachrulhajat. 2009. Diklat Mata Kuliah Pengkajian Stok Ikan. Universitas Padjadjaran.Bandung. Badrudin, 2004. Analisa Data Catch \& Effort untuk Pendugaan MSY.

Dinas Perikanan dan Kelautan Kalimantan Selatan. 2016. Laporan Statistik .

Kekenusa,S.S.,Rondonuwo,S.B.,Peandong,M.S., dan Weku,W.Ch.D. 2014. Penentuan Status Pemanfaatan dan Skenario Pengelolaan Ikan Tongkol (Auxis rochei) yang Tertangkap di Perairan Kabupaten Siau-Tagulandang-Biaro Sulawesi Utara. Manado : Jurnal Matematika dan Biologi Fakultas MIPA Universitas Samratulangi. Vol.14,.hal 137-138

Komisi Nasional Pendugaan Stok Ikan Laut. 1997. Potensi dan Penyebaran Sumberdaya Ikan Laut di Perairan Indonesia. Lembaga Ilmu Pengetahuan Indonesia. 
Nobunome, W. 2007. Model Analisis Bioekonomi dan Pengelolaan Sumberdaya Ikan Demersal (Studi Empiris di Kota Tegal, Jawa Tengah. Tesis Progam Pasca Sarjana Universitas Diponegoro :Semarang).

Riduwan. 2004. Metode Riset. Jakarta : Rineka Cipta.

Sparre, P. and S.C. Venema. 1999. Introduksi Pengkajian Stok Ikan Tropis. Buku 1 Manual. (Terjemahan J. Widodo. I.G.S. Merta, S. Nurhakim, dan M. Badrudin). Pusat Penelitian dan Pengembangan Perikanan, Badan Penelitian dan Pengembangan Pertanian (Kerjasama dengan Organisasi Pangan dan Pertanian Perserikatan Bangsa-bangsa). Jakarta. 438 hal.

Surachmad. 1980. Pengantar Penelitian Ilmiah Dasar-Dasar Metode dan Teknik. Tarsito. Bandung, 33 hal. 